\title{
Detection of Marteilia refringens using nested PCR and in situ hybridisation in Chamelea gallina from the Balearic Islands (Spain)
}

\author{
Inmaculada López-Flores ${ }^{1, *}$, Francisca Robles ${ }^{2}$, José M. Valencia ${ }^{3}$, Amalia Grau ${ }^{3}$, \\ Antonio Villalba ${ }^{4}$, Roberto de la Herrán ${ }^{2}$, Manuel A. Garrido-Ramos ${ }^{2}$, \\ Carmelo Ruiz-Rejón ${ }^{2}$, Manuel Ruiz-Rejón ${ }^{2}$, José I. Navas ${ }^{1}$
}

${ }^{1}$ IFAPA Centro Agua del Pino, Consejería de Innovación, Ciencia y Empresa, Junta de Andalucía, Carretera Cartaya-Punta Umbría, 21459 Huelva, Spain

${ }^{2}$ Departamento de Genética, Facultad de Ciencias, Universidad de Granada, 18071 Granada, Spain

${ }^{3}$ Estación de Acuicultura, D.G. Pesca, Govern Balear, Port d'Andratx, 07158 Palma de Mallorca, Spain

${ }^{4}$ Centro de Investigacións Mariñas, Consellería de Pesca e Asuntos Marítimos, Xunta de Galicia, 36620 Vilanova de Arousa, Spain

\begin{abstract}
In the course of a histopathological survey performed to discover the cause of mass mortality of the striped clam Chamelea gallina in the Balearic Islands (Spain, Mediterranean Sea), we detected a Marteilia-like parasite in 3 clams. Molecular methods were applied to identify the parasite. DNA extracted from a paraffin block was used to carry out a PCR assay for Marteilia refringens detection based on a rDNA sequence of the parasite (the intergenic spacer of ribosomal genes, IGS). The nucleotide sequence of the IGS amplified fragment and the positive signal obtained by in situ hybridisation analysis with a $M$. refringens-specific probe allowed us to confirm the presence of this parasite in the digestive gland tissue of C. gallina.
\end{abstract}

KEY WORDS: Marteilia refringens - Molecular diagnosis · rDNA · Intergenic spacer • IGS • Chamelea gallina

Resale or republication not permitted without written consent of the publisher

\section{INTRODUCTION}

Paramyxeans are a group of protists responsible for parasitosis in marine invertebrates. After a number of different taxonomic affiliations were suggested for these organisms - including the fungal order Chytridiales, the algal genus Microspora, the lower fungi and the genus Labyrinthomyxa (reviewed by Berthe et al. 2004) - Desportes \& Perkins (1990) proposed the phylum Paramyxea based on the organisms' development within the host. It is characterized by the formation of spores consisting of several cells enclosed inside one another that arise by a process of internal cleavage within a stem cell (Desportes \& Perkins 1990). The number of spores and sporal cells differentiated in the sporonts, and the shape of the spores are the principal distinguishing characters at the genus level (Desportes \& Perkins 1990, Larsson \& Køie 2005). Subsequently, the availability of DNA sequences made possible the molecular confirmation of Paramyxea as an independent eukaryotic phylum not closely related to any single phylum whose SSU rDNA sequence was known (Berthe et al. 2000, 2004). The 9 paramyxean species described so far are currently divided into 5 genera (Table 1). Certain species belonging to the genera Marteilia and Marteilioides have been the main focus of research because of the harm they cause to farmed oysters. The species Marteilia refringens has caused recurrent mass mortalities in the European flat oyster Ostrea edulis over the last 4 decades (Grizel et al. 1974, Alderman 1979, Figueras \& Montes 1988, Robert et al. 1991, Berthe et al. 2004), while Marteilia 
Table 1. Phylum Paramyxea (Desportes \& Perkins, 1990) and host in which each species has been detected

\begin{tabular}{|c|c|c|}
\hline Parasite & Host & First citation \\
\hline \multicolumn{3}{|c|}{ Class Marteiliidea (Desportes \& Ginsburger-Vogel, 1977) } \\
\hline \multicolumn{3}{|l|}{ Genus Marteilia } \\
\hline \multirow[t]{5}{*}{ M. refringens } & Ostrea edulis & Grizel et al. (1974) \\
\hline & Mytilus edulis & Tigé \& Rabouin (1976) \\
\hline & Mytilus galloprovincialis & Comps \& Joly (1980) \\
\hline & Solen marginatus & López-Flores et al. (2008) \\
\hline & Chamelea gallina & This study \\
\hline M. sydneyi & Saccostrea glomerata & Perkins \& Wolf (1976) \\
\hline M. lengehi & Saccostrea cucullata & Comps (1976) \\
\hline M. christenseni & Scrobicularia plana & Comps (1983) \\
\hline \multirow{15}{*}{ Marteilia sp. } & Cardium edule & Comps et al. (1975) \\
\hline & Crassostrea gigas & Cahour (1979) \\
\hline & Tapes pullastra & Poder et al. (1983) \\
\hline & Tapes rhomboides & Poder et al. (1983) \\
\hline & Modiolus modiolus & Auffret \& Poder (1983) \\
\hline & Ostrea chilensis & Grizel et al. (1983) \\
\hline & Ostrea angasi & Bougrier et al. (1986) \\
\hline & Ostrea puelchana & Pascual et al. (1991) \\
\hline & Argopecten gibbus & Moyer et al. (1993) \\
\hline & Tridacna maxima & Norton et al. (1993) \\
\hline & Crassostrea virginica & Renault et al. (1995) \\
\hline & Ensis minor & Ceschia et al. (2001) \\
\hline & Ensis siliqua & Ceschia et al. (2001) \\
\hline & Saccostrea forskali & Taveekijakarn et al. (2002) \\
\hline & Tapes philippinarum & Itoh et al. (2005) \\
\hline \multicolumn{3}{|l|}{ Genus Marteilioides } \\
\hline M. chungmuensis & Crassostrea gigas & Comps et al. (1986) \\
\hline M. brachialis & Saccostrea glomerata & Anderson \& Lester (1992) \\
\hline Marteilioides sp. & Tapes philippinarum & Lee et al. (2001) \\
\hline \multicolumn{3}{|l|}{ Genus Paramarteilia } \\
\hline \multirow[t]{3}{*}{ P. orchestiae } & Orchestia gammarellus & Ginsburger-Vogel et al. (1976) \\
\hline & Orchestia mediterranea & Ginsburger-Vogel (1991) \\
\hline & Orchestia aestuarensis & Ginsburger-Vogel (1991) \\
\hline \multicolumn{3}{|c|}{ Class Paramyxidea (Chatton, 1911) } \\
\hline \multicolumn{3}{|c|}{ Genus Paramyxa } \\
\hline P. paradoxa & Poecilochaetus serpens & Chatton (1911) \\
\hline \multicolumn{3}{|l|}{ Genus Paramyxoides } \\
\hline P. nephtys & Nephtys caeca & Larsson \& Køie (2005) \\
\hline
\end{tabular}

2007). Therefore, the name $M$. refringens would have taxonomic priority and this is the nomenclature we use in this study. $M$. refringens has also been reported in other bivalves (see Table 1), although the accurate identification of the parasite species has only been achieved in the mussels Mytilus edulis and Mytilus galloprovincialis and in the razor clam Solen marginatus (Table 1) by using precise histological and/or molecular methods. Among these species, mortalities have only been documented in mussels (Villalba et al. 1993a,b, Fuentes et al. 2002). The presence of the parasite in different marine species is also interesting for the study of its life cycle, in which intermediate hosts are thought to be involved. So far, only the copepod Paracartia granii has been suggested as an intermediate host in the life cycle of the parasite (Audemard et al. 2002). In addition, the existence of closely linked dynamics between $M$. refringens in mussel populations and a group of 6 different zooplankton taxa has been suggested in the coastal northeast Mediterranean near Spain (Carrasco et al. 2007a,b). In histological studies on venerid clams the presence of Marteilia sp. has been reported in Tapes rhomboides and T. pullastra (Poder et al. 1983), and in T. philippinarum (Itoh et al. 2005), but identification of the exact species involved has not so far been documented.

sydneyi has had similar effects on the Sydney rock oyster Saccostrea commercialis in Australia (Perkins \& Wolf 1976, Adlard \& Ernst 1995, Butt \& Raftos 2007). Marteilioides chungmuensis affects the gonad of the Pacific oyster Crassostrea gigas in Korea and Japan, resulting in serious economic losses for the oyster industry (Comps et al. 1986, Ngo et al. 2003, Tun et al. 2006).

In Europe, 2 molecular types or species of Marteilia have been identified: $M$. refringens (or type O), infecting oysters, and $M$. maurini (or type $M$ ), infecting mussels (Le Roux et al. 2001). Recent data suggest that parasites infecting oysters and mussels constitute 2 different strain of the species $M$. refringens (LópezFlores et al. 2004, Novoa et al. 2005, Balseiro et al.
The analysis of nucleotide sequence data has been widely used for species identification in different organisms, including Marteilia. The 18S, internal transcribed spacer-1 (ITS-1) and intergenic spacer (IGS) of the major ribosomal locus are the characterised sequences for Marteilia refringens, whereas only a partial 18S-ITS-1 sequence is known for M. sydneyi (Fig. 1). Nucleotide sequence of the $18 \mathrm{~S}$ ribosomal gene is highly conserved throughout evolution, which makes it more useful for comparing relatively distant species, in evolutionary studies for example, than as a precise molecular marker for species identification. The IGS is under little or no selective pressure; therefore its nucleotide sequence evolves quickly and it results in an appropriate marker for differentiating 


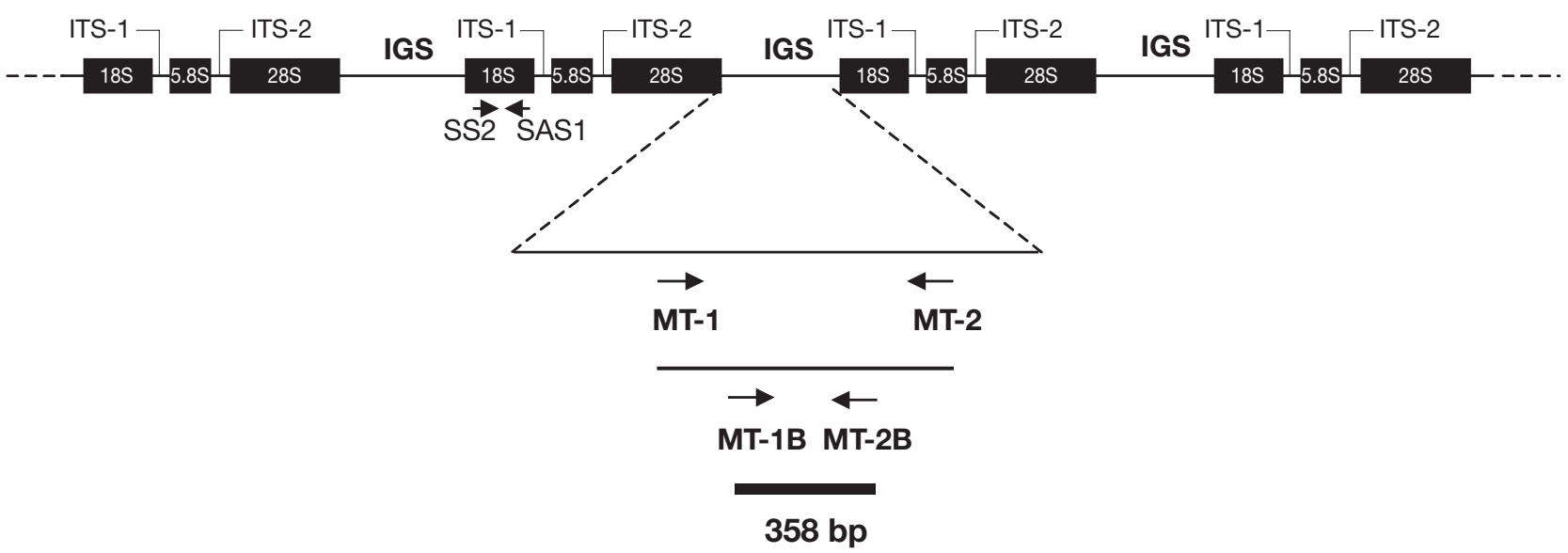

Fig. 1. Schematic representation of the ribosomal RNA gene complex containing the genes that encode rRNAs and the spacer regions. Locations of the primers used in this study are indicated

Table 2. Description of primers and their uses

\begin{tabular}{|lllcc|}
\hline Primer & Sequence $\left(5^{\prime}-3^{\prime}\right)$ & Use & Size (bp) & Reference \\
\hline MT-1 & GCCAAAGACACGCCTCTAC & First-round PCR & 525 & López-Flores \\
MT-2 & AGCCTTGATCACACGCTTT & & et al. (2004) \\
MT-1B & CGCCACTACGACCGTAGCCT & Nested-PCR, probe synthesis for ISH & 358 & López-Flores \\
MT-2B & CGATCGAGTAAGTGCATGCA & & et al. (2004) \\
SS2 & CCGGTGCCAGGTATATCTCG & Probe synthesis for ISH & Le Roux \\
SAS1 & TTCGGGTGGTCTTGAAAGGC & & et al. (1999) \\
\hline
\end{tabular}

between closely related species (Hillis \& Dixon 1991). The IGS of $M$. refringens has been used in both phylogenetic and taxonomic studies (Le Roux et al. 1999, 2001, Berthe et al. 2000, López-Flores et al. 2004, 2008 Novoa et al. 2005, Carrasco et al. 2007a,b).

In this study, we applied molecular methods for the identification of a Marteilia-like parasite found in Chamelea gallina (Bivalvia, Veneridae) in the course of a histopathological survey performed to find out the cause of a mass mortality of this clam species in the Bay of Palma (Mallorca, Balearic Islands, Spain, Mediterranean Sea). Histological and molecular analyses led to detection, for the first time, of $M$. refringens in the striped clam C. gallina.

\section{MATERIALS AND METHODS}

DNA extraction from the sample. Tissues of every sampled clam (69 individuals) were fixed in Lillie's seawater formalin solution (85\% ethanol, $10 \%$ acetic acid, $5 \%$ formalin) for $48 \mathrm{~h}$, dehydrated in an ethanol series and embedded in paraffin. Histological sections (4 $\mu \mathrm{m}$ thick) were stained with hematoxylin-eosin and observed under a light microscope for histological analysis. A Marteilia-like parasite was found in 3 of the 69 clams. Genomic DNA was obtained using twenty $5 \mu \mathrm{m}$ thick sections from the paraffin block of a clam infected by a Marteilia-like parasite. They were collected into a $1.5 \mathrm{ml}$ microcentrifuge tube and dewaxing was carried out as follows: $1 \mathrm{ml}$ of sterile ultra pure water was added to the sections prior to vortexing and incubation at $65^{\circ} \mathrm{C}$ overnight. After centrifugation at $5000 \times g$ for $5 \mathrm{~min}$, the solid paraffin in the upper layer was removed and the procedure was repeated once, this time with a shorter period of incubation at $65^{\circ} \mathrm{C}$ $(2 \mathrm{~h})$. The pellet was then processed as tissue using the High Pure PCR Template Preparation Kit (Roche) according to the manufacturer's protocol.

Detection of Marteilia refringens by nested PCR. The sequences and location of the primers used for firstround PCR and nested PCR are shown in Table 2 and Fig. 1. Both PCRs were done in a final volume of $50 \mu \mathrm{l}$ using $100 \mathrm{ng}$ of each primer (MT-1 and MT-2 for firstround PCR and MT-1B and MT-2B for nested PCR) and Ready-to-Go PCR beads (Amersham Biosciences), following manufacturer's recommendations. Different quantities of extracted DNA were used in the first ampli- 
fication (100 ng to $200 \mathrm{pg}$ ). Thermal cycling was $94^{\circ} \mathrm{C}$ for $5 \mathrm{~min}, 30$ cycles of $94^{\circ} \mathrm{C}$ for $1 \mathrm{~min}, 55^{\circ} \mathrm{C}$ for $1 \mathrm{~min}$ and $72^{\circ} \mathrm{C}$ for $1 \mathrm{~min}$, plus $72^{\circ} \mathrm{C}$ for $10 \mathrm{~min}$. For nested PCR, $2 \mu \mathrm{l}$ of first-round PCR were used as template. Thermal cycling was $94^{\circ} \mathrm{C}$ for $5 \mathrm{~min}, 25$ cycles of $94^{\circ} \mathrm{C}$ for $30 \mathrm{~s}, 60^{\circ} \mathrm{C}$ for $30 \mathrm{~s}$ and $72^{\circ} \mathrm{C}$ for $30 \mathrm{~s}$, plus $72^{\circ} \mathrm{C}$ for $5 \mathrm{~min}$. During each PCR (first-round and nested) several negative controls were used, including a non-template water sample and genomic DNA extracted from Chamelea gallina previously confirmed as non-infected by histological examination and PCR analysis. PCR products were electrophoresed in $1 \times$ TAE buffer and visualised under UV light on a $1 \%(\mathrm{w} / \mathrm{v})$ ethidium bromide-stained agarose gel. Amplified fragments obtained from 3 PCR reactions were excised from the gel and purified using a GFX ${ }^{\mathrm{TM}}$ PCR-DNA and Gel Band Purification kit (Amersham Biosciences). Nucleotide sequences were obtained using ABI Prism Dye Terminator Cycle Sequencing kit (Applied Biosystems). The protocols were carried out following the manufacturer's recommendations.

Comparison of IGS Marteilia refringens sequences purified from bivalves. To asses the genetic affinity of the sequence obtained from Chamelea gallina, IGS rDNA sequences of Marteilia refringens were downloaded from GenBank and used in a comparative analysis. Accession numbers of the sequences were as follows: $M$. refringens isolated from Ostrea edulis, AJ629352-AJ629356; M. refringens isolated from Mytilus galloprovincialis, AJ629357-AJ629376, AM748042, AM748043; M. refringens isolated from Solen marginatus, AM748037-AM748041. Multiple sequence alignment was done using the MegAlign program of the DNA package (Lasergene). Sequence variability within and between host species was calculated with the Kimura 2-parameter model distance matrix (Kimura 1980) using the MEGA package (Kumar et al. 2004).

In situ hybridisation. The probes were generated by PCR using the PCR DIG probe Synthesis Kit (Boehringer Mannheim) according to the manufacturer's instructions, and Marteilia refringens DNA was purified from Ostrea edulis as a target for the amplification reaction. Primers MT-1B and MT-2B were used for amplifying $M$. refringens IGS probe as described above for nested PCR. Primers SS2 and SAS1 were used for the synthesis of the probe Smart2, located at the $18 \mathrm{~S}$ ribosomal gene of the parasite and generic for paramyxean species, as described by Kleeman et al. (2002). See Table 2 and Fig. 1 for sequence and location of the primers. Serial sections were cut $4 \mu \mathrm{m}$ thick, placed on treated slides (Sigma) and incubated for $30 \mathrm{~min}$ at $65^{\circ} \mathrm{C}$. In situ hybridisation was performed as described elsewhere (López-Flores et al. 2008).

Negative controls, without the DIG-labelled probe in the hybridisation buffer and Saccostrea commercialis digestive gland tissue infected with Marteilia sydneyi, were included in the analysis. Positive control consisted of Ostrea edulis digestive gland tissue infected with $M$. refringens.

\section{RESULTS}

Amplified products by first-round PCR were not detectable on the agarose-stained gel with any of the DNA quantities used. However, nested PCR yielded the expected amplification product (358 bp in length) from the Chamelea gallina sample, whereas amplification was never observed in negative controls (data not shown). The sequence obtained from the amplified fragment was compared with those included in the public databases obtained from the hosts Ostrea edulis, Mytilus galloprovincialis and Solen marginatus. Nucleotide sequence of the Marteilia parasite obtained from C. gallina showed the closest identity with Marteila refringens sequences isolated from $O$. edulis (99.1\% identity with sequences isolated from $O$. edulis vs. $97.4 \%$ identity with sequences isolated from either Mytilus galloprovincialis or S. marginatus; Table 3). The partial IGS sequence of Marteilia refringens found in C. gallina has been entered into the EMBL database with accession number AM292652.

Parasite multinucleated cells were observed using histology in Haematoxylin-eosin stained sections from the striped clam sample. In some of them, the characteristic structure of Marteilia sp. of 1 cell inside another was easily distinguished. Different stages of the lifecycle were found in the epithelium of the digestive diverticula: primary cells (young stem cells) that contained only 1 nucleus, stages containing 1 or more secondary cells and more advanced stages containing up to 8 sporonts (secondary cells) within which, up to 4 spores (tertiary cells) were also visible. In advanced stages sporonts contained refringent bodies in the cytoplasm (Fig. 2A). The parasite was not detected in other organs appearing in histological sections such as gills, mantle, gonad and foot.

Table 3. Divergence (percentage) among MT-1B/MT-2B fragments from Marteilia refringens infecting Ostrea edulis, Mytilus galloprovincialis, Solen marginatus and Chamelea gallina

\begin{tabular}{|lccc|}
\hline & $\begin{array}{c}\text { O. } \\
\text { edulis }\end{array}$ & $\begin{array}{c}\text { M. gallo- } \\
\text { provincialis }\end{array}$ & $\begin{array}{c}\text { S. mar- } \\
\text { ginatus }\end{array}$ \\
\hline O. edulis & 1.4 & & \\
M. galloprovincialis & 2.0 & 1.0 & \\
S. marginatus & 1.8 & 0.7 & 0.4 \\
C. gallina & 0.9 & 2.6 & 2.6 \\
\hline
\end{tabular}



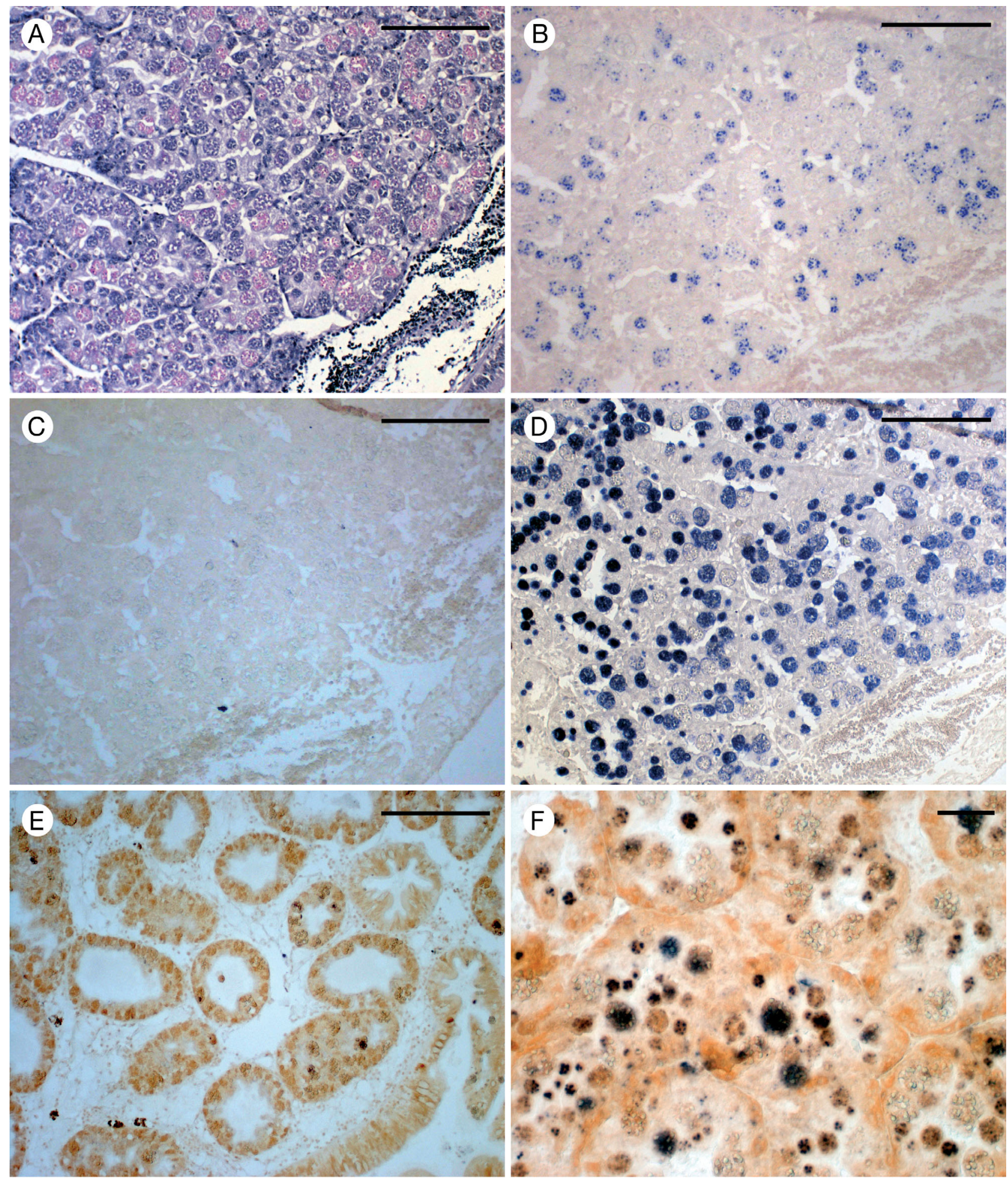

Fig. 2. Marteilia refringens cells in Chamelea gallina digestive gland sections by in situ hybridisation. (A) Classic histology with haematoxylin-eosin staining. (B) Positive hybridisation signal by digoxigenin-labelled MT-1B/MT-2B probe (M. refringens IGS probe). (C) Negative control (lack of DIG-labelled probe in the hybridisation buffer). (D) In situ control with digoxigeninlabelled Smart2 probe (Marteilia 18S ribosomal gene generic probe, Kleeman et al. 2002). (E) Saccostrea commercialis digestive gland tissue infected with Marteilia sydneyi (in situ negative control). (F) Ostrea edulis digestive gland tissue infected with 
In situ analysis performed with a Marteilia refringens IGS probe supplied hybridisation signal with the different stages of the parasite (Fig. 2B). Some of the mature cells of the parasite showed a weak hybridisation signal or no signal at all. A stronger signal was obtained with the probe targeting the $18 \mathrm{~S}$ ribosomal gene, used as a control. Equally, some cells showed no hybridisation (Fig. 2D). Ostrea edulis-infected tissue provided a positive control for $M$. refringens in situ detection (Fig. 2F). Cross hybridisation with host cells nuclei did not appear. Negative controls were used to ensure specificity and no signal was detected either in tissue sections carrying M. sydneyi infection (Fig. 2E) or in tissue section in where no probe was added (Fig. 2C).

\section{DISCUSSION}

Ethanol-fixed material was not adequately collected during routine sampling and the identification of the Marteilia-like parasite detected in Chamelea gallina had to be accomplished using paraffin-embedded tissues. However, the method we used, as discussed later in this section, was effective in identifying parasite species from fixed specimens. The methodological approach we described in this paper may have the potential to be conveniently applied for the identification of this parasite species from archival fixed tissues. Retrospective examination of archival samples by molecular techniques could enable retrospective diagnosis and provide valuable epidemiological data of $M$. refringens infection. It must be taking into account, however, that obtaining high-quality DNA from fixed paraffinembedded tissues is often difficult and failure to extract amplifiable DNA from this kind of specimen usually prevents us from obtaining molecular confirmation of the precise parasitic species present (Greer et al. 1991). In our case, the method used for $M$. refringens genome detection included first-round and nested PCR. Firstround PCR increased the primer binding sites for the second set of primers used in the nested PCR. Nested PCR therefore provides a higher sensitivity than standard PCR, since the second set of primers amplifies a secondary target present within the first amplified product. We used a combination of nested and shortlength PCR to overcome decreased efficiency of amplification by the standard PCR, probably due to extensive DNA degradation and the presence of PCR inhibitors (both of which are typical with these kinds of samples) (Greer et al. 1991, Wilson 1997).

Thus, the identification of the Marteilia-like parasite infecting Chamelea gallina was possible after amplification of a fragment of the parasite's genome by nested PCR and the comparison of its DNA sequence with the homologous sequence of $M$. refringens. The sequence obtained from the paraffin block showed 97.4\% identity with $M$. refringens sequences obtained from both Mytilus galloprovincialis and Solen marginatus. Identity with the sequences isolated from Ostrea edulis rose to $99.1 \%$. This result supports the presence of $M$. refringens in the $C$. gallina sample. Moreover, sequences isolated from $O$. edulis correspond to the molecular type of $M$. refringens that parasitizes oysters, while sequences isolated from M. galloprovincialis and $S$. marginatus correspond to the parasite strain mainly found infecting mussels (López-Flores et al. 2004, 2008). This is confirmed by the lower genetic identification between molecular types (i.e. $2 \%$ divergence between $M$. refringens from oysters and $M$. refringens from mussels, and $1.8 \%$ divergence between $M$. refringens from oyster and $M$. refringens from razor clams) than within the same type (i.e. $0.7 \%$ divergence between $M$. refringens from mussels and $M$. refringens from razor clams). Therefore, the higher identification of the parasite sequence amplified from C. gallina with the sequences isolated from $O$. edulis ( $0.9 \%$ divergence) indicates that the molecular profile of $M$. refringens infecting $C$. gallina corresponds to $M$. refringens from oysters.

Detection of Marteilia refringens in new species is interesting for the study of this parasite's life cycle and it is also of great interest for the purpose of identifying particular molecular types responsible for infections in new hosts. Recently, transmission experiments between $M$. refringens from oyster and mussels and females of the copepod Paracartia grani (the species suspected of being an intermediate host of the parasite) showed that apparently $M$. refringens from oysters proliferate more rapidly than $M$. refringens from mussels in infected copepods (Carrasco et al. 2008). Therefore, characterization at molecular level of $M$. refringens infecting different species, together with complementary studies such as mortality data and transmission experiment between the hosts, would provide valuable information for the management of bivalve production systems and marteiliosis control programs.

Specific location of Marteilia refringens cells on Chamelea gallina tissues was determined by in situ hybridisation, using probes obtained from DNA from M. refringens infecting Ostrea edulis. One of the probes was Smart2, located in the 18S ribosomal gene of the parasite and considered to be specific at Marteilia genus level (Le Roux et al. 1999, Kleeman et al. 2002). We use this probe as a control in our in situ analysis because the morphological features of the parasite in histological sections were in agreement with those described for this genus, and the result confirmed the presence of a parasite belonging to the 
genus Marteilia in C. gallina digestive gland tissue. The other probe used was the $358 \mathrm{bp}$ IGS fragment of $M$. refringens included between primers $\mathrm{MT}-1 \mathrm{~B}$ and MT-2B. The hybridisation signal obtained with the IGS probe was similar to that obtained with $O$. edulis parasitized tissue, whereas no signal was observed with cells of the related species M. sydneyi infecting Saccostrea commercialis tissues. Although the IGS rDNA sequence of $M$. sydneyi genome has not been characterized, and thus interspecific divergence between $M$. refringens and $M$. sydneyi cannot be determined based on this region, the result of the in situ hybridisation analysis in both sample and controls showed that the IGS probe can be useful for the specific identification of $M$. refringens among related species. This result, together with the identity of the sequence amplified by nested PCR, allowed us to identify the species of the genus Marteilia present in the digestive system of $C$. gallina as $M$. refringens. In addition, the weak signal of the IGS probe with respect to the probe targeting the $18 \mathrm{~S}$ gene could be explained by the lower availability of the IGS target sequence (a nontranscribed spacer only present in the genomic DNA) compared with the 18S gene sequence (present also in the transcribed rRNAs), such as has been previously described for $M$. sydneyi ITS-1 probe with respect to the same Smart2 probe (Kleeman et al. 2002). The lack of hybridisation of the IGS probe with some of the parasite cells could suggest the possible presence of another species of the Marteilia genus in the sample that did not hybridise with the $M$. refringens probe (as occurred with M. sydneyi cells in the negative control). Nevertheless, this possibility seems inconsistent, due to the fact that hybridisation with the Smart2 probe, specific at genus level, also shows a lack of signal with some parasitic cells. Therefore we consider that this result must be due to some problem in the permeabilization process during the hybridisation protocol (insufficient proteolitic enzymatic treatment) causing only partial access of the probes to the target sequence. Alternative protocols, such as the use of oligo probes, will be considered for further analysis in order to minimize this possibility during in situ hybridisation analysis.

In clams, unidentified Marteilia sp. were reported in the digestive glands of Tapes [Venerupis] pullastra and T. rhomboides from the north of France (Poder et al. 1983) and T. philippinarum from the north of Spain (Figueras et al. 1996) and Japan (Itoh et al. 2005) using histological analysis. The first record in Spain was in $T$. decussates and T. rhomboides from Galicia (Villalba et al. 1993c). In the Chamelea gallina sample, morphological characteristics of the parasite found in the digestive tubules correspond to those of the Marteilia genus (Grizel et al., 1974) and the molecular analysis we performed identified it as $M$. refringens. To our knowledge, this is the first identified Marteilia parasite in the clam C. gallina. The Mediterranean Sea is considered an enzootic area for $M$. refringens, which has been reported infecting bivalves in the nearby region of Delta del Ebro (Durfort 1994, Bigas et al. 2000, Novoa et al. 2005, Carrasco et al. 2007b); M. refringens has also been identified, using histological techniques, in the digestive gland of the European flat oyster Ostrea edulis and the mussel Mytilus galloprovincialis from the Balearic coast (Port of Maó, Minorca) (A. Grau unpubl. data), as well as in samples from the coast of Italy, Croatia and Greece (Zrncic et al. 2001, LópezFlores et al. 2004, Karagiannis \& Angelidis 2007). The presence of the different known stages of $M$. refringens cells in C. gallina, including mature sporulation stages, suggests that the parasite is able to complete the infection in this mollusc species and, therefore, $C$. gallina should be considered as a new host of $M$. refringens. A clear association between infection by $M$. refringens and C. gallina mortality in the Bay of Palma could not be established because only 3 of the 69 clams were found to be infected. Nevertheless, the causes of this high mortality have yet to be discovered. Further research, including transmission experiments of the parasite, is required to assess whether C. gallina species has been identified as another host for $M$. refringens or whether it plays another role in the life cycle of the parasite.

Acknowledgements. This research was supported by grants from the Plan Andaluz de Investigación (Group No. CVI0200), Project No. C03-082 from the IFAPA, Consejería de Innovación, Ciencia y Empresa de la Junta de Andalucía and by a postdoctoral fellowship (IFAPA, Consejería de Innovación, Ciencia y Empresa de la Junta de Andalucía) to I.L.F.. We thank Dr. I. Arzul (IFREMER, Station La Tremblade) for providing Saccostrea commercialis samples infected with Marteilia sydneyi. We also thank our colleague N. Walkington for revising our English text.

\section{LITERATURE CITED}

Adlard RD, Ernst I (1995) Extended range of the oyster pathogen, Marteilia sydneyi. Bull Eur Assoc Fish Pathol 15:119-121

Alderman DJ (1979) Epizootiology of Marteilia refringens in Europe. Mar Fish Rev 41:67-69

Anderson TJ, Lester RJG (1992) Sporulation of Marteilioides branchialis n. sp. (Paramyxea) in the Sydney rock oyster, Saccostrea commercialis: an electron microscope study. J Protozool 39:502-508

Audemard C, Le Roux F, Barnaud A, Collins C and others (2002) Needle in a haystack: involvement of the copepod Paracartia grani in the life-cycle of the oyster pathogen Marteilia refringens. Parasitology 124:315-323

Auffret M, Poder M (1983) Recherches sur Marteilia maurini, parasite de Mytilus edulis sur les côtes de Bretagne nord. Rev Trav Inst Pêch Marit 47:105-109 
Balseiro P, Montes A, Ceschia G, Gestal C, Novoa B, Figueras A (2007) Molecular epizootiology of the European Marteilia spp., infecting mussels (Mytilus galloprovincialis and M. edulis) and oysters (Ostrea edulis): an update. Bull Eur Assoc Fish Pathol 27:148-156

Berthe FCJ, Le Roux F, Peyretaillade E, Peyret P, Rodriguez D, Gouy M, Vivares P (2000) Phylogenetic analysis of the small subunit ribosomal RNA of Marteilia refringens validates the existence of phylum Paramyxea (Desportes and Perkins, 1990). J Eukaryot Microbiol 47:288-293

Berthe FCJ, Le Roux F, Adlard RD, Figueras A (2004) Marteiliosis in molluscs: a review. Aquat Living Resour 17: 433-448

Bigas M, Sagristà E, Bozzo G, Durfort M, Poquet M (2000) Ocurrence of heavy metals and protozoan parasites in the mussel, Mytilus galloprovincialis, collected in the western Mediterranean. Ecotoxicol Environ Saf 3:16-21

Bougrier S, Tigé G, Bachere E, Grizel H (1986) Ostrea angasi acclimatization to French coasts. Aquaculture 58:151-154

Butt D, Raftos DA (2007) Immunosuppression in Sydney rock oysters (Saccostrea glomerata) and QX disease in the Hawkesbury River, Sydney. J Mar Freshw Res 58:213-221

Cahour A (1979) Marteilia refringens and Crassostrea gigas. Mar Fish Rev 41:19-20

Carrasco N, López-Flores I, Alcaraz M, Furones MD, Berthe FCJ, Arzul I (2007a) First record of a Marteilia parasite (Paramyxea) in zooplankton populations from a natural estuarine environment. Aquaculture 269:63-70

Carrasco N, López-Flores I, Alcaraz M, Furones MD, Berthe FCJ, Arzul I (2007b) Dynamics of the parasite Marteilia refringens (Paramyxea) in Mytilus galloprovincialis and zooplankton populations in Alfacs Bay (Catalonia, Spain). Parasitology 134:1541-1550

Carrasco N, Arzul I, Chollet B, Robert M, Joly JP, Furones MD, Berthe FCJ (2008) Comparative experimental infection of the copepod Paracartia grani with Marteilia refringens and Marteilia maurini. J Fish Dis 31:497-504

Ceschia G, Zanchetta S, Sello M, Montes F, Figueras A (2001) Presenza di parassiti in cannolicchi (Ensis minor e Ensis siliqua) pescati nell'area costiera del Mar Tirreno medidionale e del Mar Adriatico. Bol Soc Ital Pathol Ittica 13:20-27

Chatton E (1911) Sur une Cnidosporidie sans cnidoblaste (Paramyxa paradoxa, n. g., n. sp.). CR Acad Sci Paris 152: 631-633

Comps M (1976) Marteilia lengehi n. sp., parasite de l'huître Crassostrea cucullata Born. Rev Trav Inst Pêch Marit 40: 347-349

Comps M (1983) Étude morphologique de Marteilia christenseni sp. n. parasite du lavignon Scrobicularia piperata $\mathrm{P}$ (mollusque pélécypode). Rev Trav Inst Pêch Marit 47: 99-104

Comps M, Joly JP (1980) Contamination expérimentale de Mytilus galloprovincialis Lmk par Marteilia refringens. Sci Pêche 301:19-21

Comps M, Grizel H, Tigé G, Duthoit JL (1975) Parasites nouveaux de la glande digestive des mollusques marins Mytilus edulis L. et Cardium edule. CR Acad Sci Paris Sér D 281:179-181

Comps M, Park MS, Desportes I (1986) Étude ultraestructurale de Marteilioides chungmuensis n. g., n. sp. parasite des ovocytes de l'huître Crassostrea gigas. Protistologica 22:279-285

Desportes I, Perkins FO (1990) Phylum Paramyxea. In: Margulis L, Corliss JO, Melkonian M, Chapman DJ (eds) Handbook of Protoctista. Jones and Barlett Publishing, Boston, MA, p 30-35
Durfort M (1994) Revisión de las parasitosis más frecuentes de los moluscos bivalvos de interés comercial del mar catalán (Mediterráneo). In: Castelló F, Calderer (eds) Actas del V Congreso Nacional de Acuicultura, May 10-13, 1995, S. Carlos de la Rápita, Spain, Universidad de Barcelona, p 52-62

Figueras AJ, Montes J (1988) Aber disease of edible oysters caused by Marteilia refringens. Am Fish Soc Spec Publ $18: 38-46$

Figueras A, Robledo JAF, Novoa B (1996) Brown ring disease and parasites in clams (Ruditapes decussatus and $R$. philippinarum) from Spain and Portugal. J Shellfish Res 15:363-368

Fuentes J, López JL, Mosquera E, Vázquez J, Villalba A, Álvarez G (2002) Growth, mortality, pathological conditions and protein expression of Mytilus edulis and M. galloprovincialis crosses cultured in the Ria de Arousa (NW of Spain). Aquaculture 213:233-251

Ginsburger-Vogel T (1991) Intersexuality in Orchestia mediterranea Costa, 1853, and Orchestia aestuarensis Wildish, 1987 (Amphipoda): a consequence of hybridisation or parasitic infestation? J Crustac Biol 11:530-539

Ginsburger-Vogel T, Desportes I, Zerbib C (1976) Présence chez l'amphipode Orchestia gammarellus (Pallas) d'un protiste parasite, ses affinités avec Marteilia refringens agent de l'épizootie de l'huître plate. CR Acad Sci Paris 283:939-942

Greer CE, Peterson SL, Kiviat NB, Manos MM (1991) PCR amplification from paraffin-embedded tissues - effects of fixative and fixation time. Am J Clin Pathol 95: $117-124$

Grizel H, Cops M, Bonami JR, Cousserans F, Duthoit JL, Le Pennec MA (1974) Recherche sur l'agent de la maladie de la glande digestive de Ostrea edulis Linnè. Bull Inst Pêches Marit 240:7-30

Grizel H, Comps M, Raguenes D, Leborgne Y, Tigé G, Martin AG (1983) Bilan des essais d'acclimatation d'Ostrea chilensis sur les côtes de Bretagne. Rev Trav Inst Pêches Marit 46:209-225

Hillis DM, Dixon MT (1991) Ribosomal DNA: molecular evolution and phylogenetic inference. Q Rev Biol 66:411-453

Itoh N, Momoyama K, Ogawa K (2005) First report of three protozoan parasites (a haplosporidian, Marteilia sp. and Marteilioides sp.) from the Manila clam, Venerupis (= Ruditapes) philippinarum in Japan. J Invertebr Pathol 88:201-206

Karagiannis D, Angelidis P (2007) Infection of cultured mussels Mytilus galloprovincialis by the protozoan Marteilia sp. in the Thermaikos Gulf (N Greece). Bull Eur Assoc Fish Pathol 27:131-141

Kimura M (1980) A simple method for estimating evolutionary rate of base substitution through comparative studies of nucleotide sequences. J Mol Evol 16:111-120

Kleeman SN, Le Roux F, Berthe F, Adlard RD (2002) Specificity of PCR and in situ hybridisation assays designed for detection of Marteilia sydneyi and M. refringens. Parasitology 125:131-141

Kumar S, Tamura K, Jakobsen IB, Nei M (2004) MEGA3: integrated software for molecular evolutionary genetic analysis and sequence alignment. Brief Bioinform 5:150-163

Larsson JIR, Køie M (2005) Ultrastructural study and description of Paramyxoides nephtys gen. n. sp. n. a parasite of Nephtys caeca (Fabricius, 1780) (Polychaeta: Nephtyidae). Acta Protozool 44:175-187

Le Roux F, Audemard C, Barnaud A, Berthe F (1999) DNA probes as potential tools for the detection of Marteilia refringens. Mar Biotechnol 1:588-597 
Le Roux F, Lorenzo G, Peyret P, Audemard C and others (2001) Molecular evidence for the existence of two species of Marteilia in Europe. J Eukaryot Microbiol 48: 449-454

Lee MK, Cho BY, Lee SY, Kang JY, Joeng HD, Huh SH, Huh MD (2001) Histopathological lesions of Manila clam, Tapes philippinarum, from Hadong and Namhae coastal areas of Korea. Aquaculture 201:199-209

López-Flores I, de la Herran R, Garrido-Ramos MA, Navas JI Ruiz-Rejón C, Ruiz-Rejón M (2004) The molecular diagnosis of Marteilia refringens and differentiation between Marteilia strains infecting oysters and mussels based on the rDNA IGS sequence. Parasitology 129:411-419

López-Flores I, Garrido-Ramos MA, de la Herran R, RuizRejón C, Ruiz-Rejón M, Navas JI (2008) Identification of Marteilia refringens infecting the razor clam Solen marginatus by PCR and in situ hybridization. Mol Cell Probes 22:151-155

Moyer MA, Blake NJ, Arnold WS (1993) An ascetosoporan disease causing mass mortality in the Atlantic calico scallop, Argopecten gibbus (Linnaeus, 1758). J Shellfish Res $12: 305-310$

> Ngo TTT, Berthe FCJ, Choi KS (2003) Prevalence and infection intensity of the ovarian parasite Marteilioides chungmuensis during an annual reproductive cycle of the oyster Crassostrea gigas. Dis Aquat Org 56:259-267

Norton JH, Perkins FP, Ledua E (1993) Marteilia-like infection in a giant clam Tridacna maxima in Fiji. J Invertebr Pathol 61:328-330

Novoa B, Posada D, Figueras A (2005) Polymorphisms in the sequences of Marteilia internal transcribed spacer region of the ribosomal RNA genes (ITS-1) in Spain: genetic types are not related with bivalve hosts. J Fish Dis 28:331-338

Pascual M, Martin AG, Zampatti E, Coatanea D, Defossez J, Robert R (1991) Testing of the Argentina oyster, Ostrea puelchana, in several French oyster farming sites. ICES CM/K:30. ICES, Copenhagen

Perkins F, Wolf P (1976) Fine structure of Marteilia sydneyi sp. n. Haplosporidian pathogen of Australian oysters. J Parasitol 62:528-538

Poder M, Auffret M, Balouet G (1983) Études pathologiques et épidémiologiques des lésions parasitaires chez Ostrea edulis L. Premiers résultants d'une recherche prospective

Editorial responsibility: Stephen Feist, Weymouth, UK comparative chez les principales espèces de mollusques des zones ostréicoles de Bretagne nord. In: Colloques sur les bases biologiques de l'aquaculture, Dec 12-16. CNRSCNEXO, Montpellier, p 125-138

Renault T, Cochennec N, Chollet B (1995) Marteiliosis in American oysters Crassostrea virginica reared in France. Dis Aquat Org 23:161-164

Robert R, Borel M, Pichot Y, Trut G (1991) Growth and mortality of the European oyster Ostrea edulis in the Bay of Arcachon (France). Aquat Living Resour 4:265-274

Taveekijakarn P, Nash G, Somsiri T, Putinaowarat S (2002) Marteilia-like species: first report in Thailand. AAHRI Newsl 11:1-2

Tigé G, Rabouin MA (1976) Étude d'un lot de moules transférées dans un centre touché par l'épizootie affectant l'huître plate. ICES CM/K:21. ICES, Copenhagen

Tun KL, Itoh N, Komiyama H, Ueki N, Yoshinaga T, Ogawa K (2006) Comparison of Marteilioides chungmuensis infection in the Pacific oyster Crassostrea gigas cultured in different conditions. Aquaculture 253:91-97

Villalba A, Mourelle SG, Carballal MJ, López MC (1993a) Effects of infection by the protistan parasite Marteilia refringens on the reproduction of cultured mussels Mytilus galloprovincialis in Galicia (NW Spain). Dis Aquat Org 17:205-213

Villalba A, Mourelle SG, Lopez MC, Carballal MJ, Azevedo C (1993b) Marteiliasis affecting cultured mussels Mytilus galloprovincialis of Galicia (NW Spain). I. Etiology, phases of the infection and temporal and spatial variability in prevalence. Dis Aquat Org 16:61-72

Villalba A, López MC, Carballal MJ (1993c) Parásitos y alteraciones patológicas de tres especies de almeja, Ruditapes decussatus, Venerupis pullastra y Venerupis rhomboides, en las rías gallegas. In: Cerviño A, Landín A, de Coo A, Guerra A, Torres M (eds) Actas IV Congreso Nacional de Acuicultura. Centro de Investigacións Mariñas, Vilanova de Arousa, p 551-556

Wilson IG (1997) Inhibition and facilitation of nucleic acid amplification. Appl Environ Microbiol 63:3741-3751

Zrncic S, Le Roux F, Oraic D, Sostaric B, Berthe FCJ (2001) First record of Marteilia sp. in mussels Mytilus galloprovincialis in Croatia. Dis Aquat Org 44:143-148

Submitted: January 31, 2008; Accepted: July 11, 2008

Proofs received from author(s): September 20, 2008 